\title{
Effect of a combination of medium chain triglycerides, linoleic acid, soy lecithin and vitamins $A$ and $E$ on wound healing in rats ${ }^{1}$
}

\author{
Efeito da combinação de triglicerídeos de cadeia média, ácido linoléico, lecitina de soja e \\ vitaminas A e E na cicatrização de ferida em ratos
}

\begin{abstract}
Maria Sonia Felício Magalhães ${ }^{\mathrm{I}}$, Francisco Vagnaldo Fechine ${ }^{\mathrm{II}}$, Rafael Nogueira de Macedo ${ }^{\mathrm{III}}$, Diego Levi Silveira Monteiro ${ }^{\mathrm{III}}$, Cecília Carvalho Oliveira $^{\text {IV }}$, Gerly Anne de Castro Britov ${ }^{\mathrm{V}}$, Maria Elisabate Amaral de Moraes ${ }^{\mathrm{VI}}$, Manoel Odorico de Moraes ${ }^{\mathrm{VI}}$
\end{abstract}

${ }^{I}$ Fellow PhD degree, Department of Surgery, Federal University of Ceará (UFC), Brazil.

II PhD, Department of Physiology and Pharmacology, UFC, Brazil.

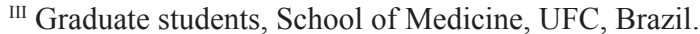

IV Fellow Master degree, Pharmacology, UFC, Brazil.

${ }^{v} \mathrm{PhD}$, Associate Professor, Department of Morfology and Histology, UFC, Brazil.

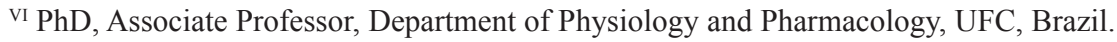

\begin{abstract}
Purpose: The aim of the study was to determine the effect of a combination of medium chain triglycerides (caprylic, capric, caproic and lauric acids), linoleic acid (essential fatty acid), vitamins A and E and soy lecithin, through a morphometric study, on the wound healing kinetics of experimental cutaneous ulcers. Methods: A total of 45 male Wistar rats were used, in which a skin flap of total thickness with an area of $4 \mathrm{~cm}^{2}$ was removed. The animals were divided randomly into 3 groups of 15 rats each, Control, Reference and Test groups, which were treated topically with $0.9 \% \mathrm{NaCl}$, a preparation of clostebol combined with neomycin sulfate and the test formulation, respectively. The wound areas were measured by digital planimetry at days zero, 3, 7 and 12 postoperative. Based on the wound area, we determined the degree of tissue repair and mean rate of repair at different time intervals. Results: At day 3, an expansion of the wound area was observed in the Reference group and slight contraction in the Control and Test groups. On the subsequent days, the healing process, according to the degree of repair, proceeded in a linear manner, such that, at day 12 , the healed area reached $77.95 \%$ of the initial ulcerated region in the Control group, $78.40 \%$ in the Reference group and $83.49 \%$ in the Test group, showing no significant differences. The overall mean rate of repair was equally similar at 12 days of treatment: $25.79 \mathrm{~mm}^{2} / \mathrm{dia}$ in the Control group, $25.42 \mathrm{~mm}^{2} /$ dia in the Reference group and $27.38 \mathrm{~mm}^{2} / \mathrm{dia}$ in the Test group. Conclusion: The test preparation, applied topically on the experimentally induced cutaneous ulcers in rats, did not accelerate the process of tissue repair by secondary union.
\end{abstract}

Key words: Triglycerides. Linoleic Acid. Wound Healing. Rats.

\section{RESUMO}

Objetivo: Avaliar o efeito da associação de triglicerídeos de cadeia média (ácidos caprílico, cáprico, capróico e láurico), ácido linoléico (ácido graxo essencial), vitaminas A e E e lecitina de soja, através de estudo morfométrico, na cinética de reparação de úlceras cutâneas experimentais. Métodos: Utilizaram-se 45 ratos, machos, da linhagem Wistar, nos quais foi removido um retalho cutâneo de espessura total com $4 \mathrm{~cm}^{2}$ de área. Os animais foram divididos aleatoriamente em 3 grupos constituídos de 15 ratos, Controle, Referência e Teste, que foram tratados por via tópica respectivamente, com solução salina $0,9 \%$, composto de clostebol associado a sulfato de neomicina e a formulação em teste. As áreas das feridas foram mensuradas por planimetria digital nos dias zero, 3, 7 e 12 de pós-operatório. A partir da área da ferida, calcularam-se ainda o grau de reparação e a taxa média de reparação em intervalo de tempo. Resultados: No 3o dia observou-se uma expansão da área da ferida no grupo referência e uma leve contração nos grupos controle e teste. Nos dias subseqüentes o processo de reparação, medido pela variável grau de reparação, evoluiu de forma linear, de modo que, no $12^{\circ}$ dia, a área reparada alcançou 77,95\% da região ulcerada inicial no grupo Controle, $78,40 \%$ no grupo Referência e $83,49 \%$ no grupo Teste, não sendo constatadas diferenças estatisticamente significante. Igualmente semelhantes foram os valores da taxa média de reparação referente aos 12 dias de tratamento: $25,79 \mathrm{~mm}^{2} /$ dia no grupo Controle, 25,42 $\mathrm{mm}^{2} /$ dia no grupo Referência e $27,38 \mathrm{~mm}^{2} /$ dia no grupo Teste Conclusão: O composto em Teste, aplicado por via tópica em úlceras cutâneas experimentalmente induzidas em ratos, não acelerou o processo de reparação recidual por segunda intenção. Descritores: Triglicerídeos. Ácido Linoléico. Cicatrização de Feridas. Ratos.

1. Research perfomed at Experimental Surgical Research Laboratory (LABCEX), Department of Surgery, Post-Graduation Program, Federal University of Ceará (UFC), Brazil. 


\section{Introduction}

The phenomenon of wound healing permits surgical interventions to be performed in animals. In antiquity, humans observed that wounds sustained from injuries closed themselves after a period of time. Hippocrates conducted studies on wounds and noted that tissues have the power of natural wound healing. Some studies were conducted on wound healing, but based on empirical observations in battle injuries. In the beginning of the $\mathrm{XX}^{\text {th }}$ century, studies on laboratory animals were begun, comparing wounds in humans. From then on, experimentations intensified and permitted a greater understanding of this subject ${ }^{1}$.

The wound healing process consists of the perfect and coordinated cascade of cellular and molecular events that interact to bring about the repair and reconstitution of the tissue ${ }^{2}$. This is a dynamic process that involves biochemical and physiological phenomena occurring in a harmonious manner to guarantee tissue restoration.

The wound can be defined as any alteration in the anatomic integrity of the skin, resulting from any type of trauma, where it can even be classified as intentional (surgical incisions) or accidental ${ }^{3}$. Wound healing by secondary union are submitted to the influence of various factors that can contribute to the delay of wound healing, resulting in the majority of cases in inflammation, edema and hypertrophic and unesthetic scars. All wounds, regardless of their etiology, are a disruption of continuity in the tissue, which results in the interruption of blood flow, in the perturbation of sensitivity, in the accumulation of dead cell debris and in a variable degree of contamination (with or without infection). With the aim of restoring the integrity of the skin, the organism utilizes a complex mechanism called wound healing ${ }^{4}$.

The process of wound healing begins immediately after the lesion and comprises the inflammatory, proliferative and maturation phases. The inflammatory phase is characterized by the recruitment of leukocytes, such as neutrophils and macrophages, to the lesion site. In the proliferative phase, the migration and proliferation of keratinocytes, fibroblasts and endothelial cells result in re-epithelization and formation of granulation tissue. Finally, in the maturation phase, the excess of collagen is degraded various proteolytic enzymes promoting complete tissue repair 5 .

The substance tested here is a oily formulation marketed as a hydrating oil and dermoprotector for topical use, with basic composition consisting of medium chain triglycerides (caprylic, capric, caproic and lauric acids) and linoleic acid (essential fatty acid), vitamins A and E and soy lecithin.

MCT (medium chain triglycerides) contain in their structure predominantly fatty acids with eight carbons (caprylic), ten carbons (capric), six carbons (caproic) and twelve carbons (lauric). The triacylglicerols of capric and caprylic acids deserve special attention as esters. In being classified as MCT, they are useful as a nutritional source, solvent, and vehicle and stabilizer of products to be administered orally, topically or parenterally. They can have uses in the treatment and prevention of ammoniacal dermatitis and bedsores, by forming a protective barrier for the skin, impeding maceration, besides being of importance in processes of cellular inflammation, providing alleviaton after first application, and local cell nutrition, in addition to having a great capacity of tissue regeneration. Medium chain fatty acids, such as monoacylglycerols, have been shown to have antimicrobial activity, reducing the formation of dental caries in a study conducted in laboratory animals ${ }^{6}$.

Fatty acids belong to a class of compounds formed by a long hydrocarbon chain and a terminal carboxylic group. They have three main functions: they are structural components of biological membranes, they act as precursors of intracellular messengers and they are oxidized producing ATP (adenosine triphosphate) $)^{7}$.

From the beginning of the 1970s, there have been studies on the effects of fatty acids on the immune response. Such compounds interfere with various events of the inflammatory process, such as vascular contraction, chemotaxis, adhesion, diapedesis, activation and cell death, where the majority of these occur via arachidonic acids such as prostaglandins, leukotrienes, tromboxanes and lipoxins ${ }^{7}$.

PUFAs (polyunsaturated fatty acids) should be pointed out among the various fatty acids present in the plasma and in leukocytes. Besides their structural function, they can modulate cell-cell interactions and intracellular signaling. Thus, the alteration of the composition of fatty acids of phospholipids in the cell membrana can modify fluidity and change the binding of cytokines to their receptors ${ }^{8}$.

Vitamin A interferes with wound healing causing lysis of lysosomal membranes stimulation fibroblasts and collagen deposition ${ }^{9}$. The biological activities of vitamin A have not been completely elucidated, but it appears to act as an antiinflammatory agent and its antioxidant properties suggest a protective function for growing cells against oxygen radicals released by leukocytes ${ }^{10}$.

Studies have shown that besides essential fatty acids, soy lecithin and vitamins $\mathrm{A}$ and $\mathrm{E}$ also contribute to the process of tissue repair. Soy lecithin, besides being a protective agent, provides maintenance of tissue hydration and helps in the process of wound healing of the skin 9 .

Linoleic acid is an essential fatty acid of 18 carbons. Through a desaturation process, it gives rise to arachidonic acid (20 carbons), a precursor of prostaglandins, leukotrienes, thromboxanes and lipoxins, which in turn act as mediators of platelet function and of inflammatory, vascular, motor and sensory processes, among others ${ }^{2,7}$.

It has been observed that linoleic acid is capable of inhibiting the growth of Staphylococcus aureus by altering its protein synthesis, cell wall, nucleic acids and cell membrane during division ${ }^{11}$.

Linoleic acid has also been shown to participate in cell proliferation and inflammatory process, where in the latter it plays a role as a mediator of leukocyte function having chemotactic and stimulatory effects on neutrophils ${ }^{12}$.

Since antiquity, humans developed the capacity to perform relatively reliable measurements. Primitive human populations performed astronomical measurements for religious and agricultural purposes, for the construction of religious temples, palaces and houses. During the Industrial Revolution, there was a standarization of weights and measures with the introduction 
of the decimal metric system in France.

The word morphometry is formed from the Greek prefix morphe which means shape, combined with the Greek suffix metrikos, or in Latin metricu, which means the act of measuring or the process of establishing dimensions ${ }^{13}$.

This term has a wide application in science, but in biomedicine its meaning is measurement of anatomic structures. It is a method for the purpose of giving more objectivity and precision to the collection, presentation and analysis of results in research and routine laboratory work, thereby permitting anatomical structures to be compared like functions. Some morphometric measurements are areas (surfaces), weights, volumes, lengths, angles, diameters and perimenters. These are measurements that can be determined in microscopic, mesoscopic and macroscopic structures ${ }^{13,14}$.

The measurement of areas can be performed with accuracy utilizing different planimetric methods, among which is planimetry by linear integration and by counting points. Such techniques are applicable only with flat images ${ }^{14}$.

The advent of computational systems for the processing of digital images made it possible to carry out planimetric measurements that are more objective, rapid and accurate ${ }^{13}$.

The aim of this work was to determine the effect of the combination of medium chain triglycerides (caprylic, capric, caproic and lauric acids), linoleic acid (essential fatty acid), vitamins $\mathrm{A}$ and $\mathrm{E}$ and soy lecithin, on the tissue repair kinetics of experimental cutaneous ulcers, by means of a morphometric study.

\section{Methods}

The study was conducted in the Laboratory of Experimental Surgery in the Department of Surgery of the Federal University of Ceara (UFC) following the protocol No 31/05, approved by the Committee on Ethics in Animal Research (CEPA) of the same instituition, which was in accordance with the Ethical Principles in Animal Experimentation adopted by the Brazilian College of Animal Experimentation (COBEA).

A total of 45 male Wistar rats (Rattus norvegicus) were used, with a mean body weight of $149.69 \mathrm{~g}$ varying from 106 to $171 \mathrm{~g}$, obtained from the Central Animal Facility of UFC. The animals were previously examined with respect to general health conditions, and received an appropriate balanced ration for the species and water ad libitum. The animals were housed in individual cages without sawdust, so that it would not stick to the wounds; a paper bottom was provided which was changed daily. They were kept at room temperature with controled humidity and a 12-h photoperiod.

The surgical wound model utilized involved the removal of a skin flap of full thickness on the back of the animal. The rats were initially anesthesized with an intraperitoneal injection of ketamine hydrochoride $(90 \mathrm{mg} / \mathrm{kg}$ ) and xylazine hydrochloride $(10 \mathrm{mg} / \mathrm{kg})$, and the dorsal was then shaved. Afterward, a $2 \times 2 \mathrm{~cm}\left(4 \mathrm{~cm}^{2}\right)$ area was outlined with a template made of cellulose film, on the dorsal medial line, caudally corresponding to the forelimbs. Incisions were made on the skin and the square skin flap was removed.
The rats were divided randomly into 3 groups consisting of 15 animals each: Control, Reference and Test. From the first day postoperative up to the $12^{\text {th }}$ day of treatment, the wounds were cleaned daily with isotonic saline $(0.9 \% \mathrm{NaCl})$ in the three groups. In the Reference group, the wound was treated with a daily topical application of a fine layer $(0.5232 \mathrm{~g})$ of a cream composed of clostebol acetate and neomycin sulfate. In the Test group, the wound was treated once a day with a topical application of $0.1435 \mathrm{~g}$ of test solution containing medium chain triglycerides, linoleic acid, vitamins $\mathrm{A}$ and $\mathrm{E}$ and soy lecithin.

Digital images of the ulcers were taken, in vivo, in a standardized manner, immediately after the surgical procedure (day zero) and on days 3, 7 and 12 postoperative. An analog video camera (Hitachi VCC-151, Japan) was used coupled to a surgical microscope (D.F. Vasconcellos M90, D.F. Vasconcellos S.A., São Paulo, Brazil), whose signal was transferred to a video capture plate (PixelView PV-TV304P, Prolink Microsystems Corp., Taiwan) installed in a microcomputer. The axis of the microscope was fixed perpendicular to the horizontal plane, keeping the objective at a distance of $33 \mathrm{~cm}$ from this plane. Such distance provided optimal focusing of the ulcer, with a magnification of $6 \mathrm{X}$, when the animal was in the ventral decubitus position, on the horizontal plane, with the center of the ulcer coinciding with the center of the microscope field. The digitized images were stored in Windows Bitmap (BMP) format, with the dimensions of 320x240 pixels, each pixel corresponding to 24 bits, based on the red, green, blue (RGB) color model.

A computer program was developed specifically for the measurement of the area of the ulcer in digital images. The operator first outlined the borders of the ulcer with the mouse (Figure 1). Next, the software automatically cut out the outlined region and calculated its area (A) in $\mathrm{mm}^{2}$, according to the scale factor (number of pixels $/ \mathrm{mm}$ with respect to the magnification and dimension utilized) previously determined. Subsequently, the region of the ulcer was reinserted into the original image, colored blue, so that the user could determine if the delimitation of the area had been performed properly (Figure 2).

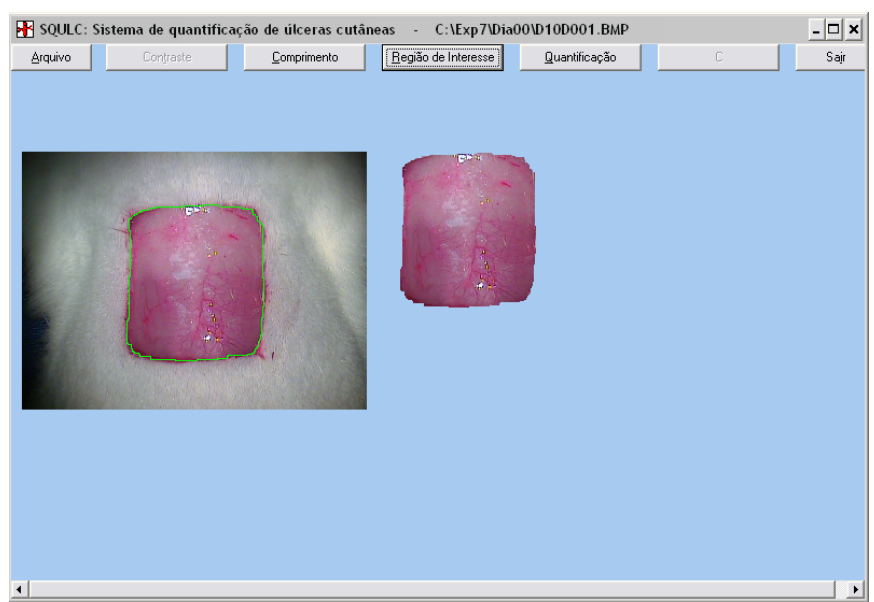

FIGURE 1 - Delimitation of the ulcer area 


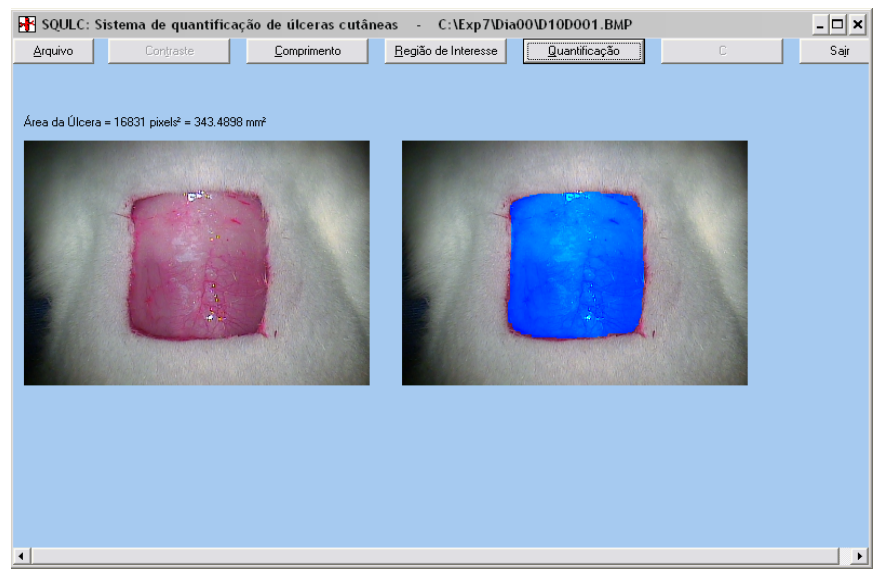

FIGURE 2 - Quantification of the ulcer area

The degree of wound repair $(D R)$ of the ulcers was determined on days 3, 7 and 12, where it was calculated based on the initial area (measured on day zero) and expressed as a percentage, according to the following formula ${ }^{15,16}$.

$$
D R_{i}=\frac{A_{0}-A_{i}}{A_{0}} \cdot 100
$$

where $D R_{i}$ denotes the degree of wound repair for day $i$ and $A_{0}$ and $A_{i}$ correspond to the area of the ulcer on days zero and $i$, respectively.

Also calculated was the mean rate of wound repair $(R R m)$, which denotes how many $\mathrm{mm}^{2}$ the area of the ulcer decreased for a given time interval $t_{1}$ to $t_{2}$, where it was expressed in $\mathrm{mm}^{2} /$ day and defined by the quotient:

$$
R R m=-\frac{A\left(t_{2}\right)-A\left(t_{1}\right)}{t_{2}-t_{1}}
$$

where $A\left(t_{1}\right)$ and $A\left(t_{2}\right)$ are the areas of the ulcera at times $t_{1}$ and $t_{2}$, respectively, and $t_{2}>t^{1}$.

The efficacy $(E)$ of a given treatment was calculated on day 12 , where it was defined with respect to the Control group and expressed as a percentage based on the following formula:

$$
E=\frac{D R_{12}(T)-D R_{12}(C)}{D R_{12}(C)} .100
$$

where $D R_{12}(C)$ and $D R_{12}(T)$ correspond to the mean degree of healing determined on day 12 in the Control group and treated (Reference and Test) groups, respectively.

The data were initially evaluated by the KolmogorovSmirnov test to verify normality of the distribution. Since such requirement was observed for all the variables, we then calculated for descriptive statistics the mean and standard deviation, and parametric tests were utilized for analysis of the data as well. Comparisons among the Control, Reference and Test groups, for a given day or interval, were performed by use of analysis of variance (ANOVA), combined with Tukey's test for multiple comparisons, to determine differences among the groups two by two. The level of significance set at $5 \%$. The statistics software GraphPad Prism ${ }^{\circledR}$ version 4.03 for Windows ${ }^{\circledR}$ (GraphPad Software, San Diego, California, USA, 2005) was used for both the analysis of the data and the construction of the graphs.

\section{Results}

In evaluating the temporal progression of tissue repair from a macroscopic point of view, it was seen that in the first days, there was an expansion of the ulcerated area in the Reference group, while in the Control and Test groups the wound decreased in area. From the $3^{\text {rd }}$ to $7^{\text {th }}$ day, the presence of fibrin was observed in the Reference group, a scab began to form in the Control group, and the wound remained moist with granulation tissue in the Test group. In the interval from the $7^{\text {th }}$ to the $12^{\text {th }}$ day, healing was more evident in the Control and Test group with the presence of a scab, while there was an initial appearance of a tenuous scab in the Reference group but with a more enlarged area in relation to the other groups. Macroscopic evidence of better healing was only observed from the $7^{\text {th }}$ to the $12^{\text {th }}$ day, when the scab fell off in the Control and Test groups, while in the Reference group, although the ulcerated area was still larger than in the other groups, wound healing was more homogeneous. On the $12^{\text {th }}$ day, although complete wound healing was not demonstrated in any of the groups, the wound was smallest in the Test group (Figure 3).

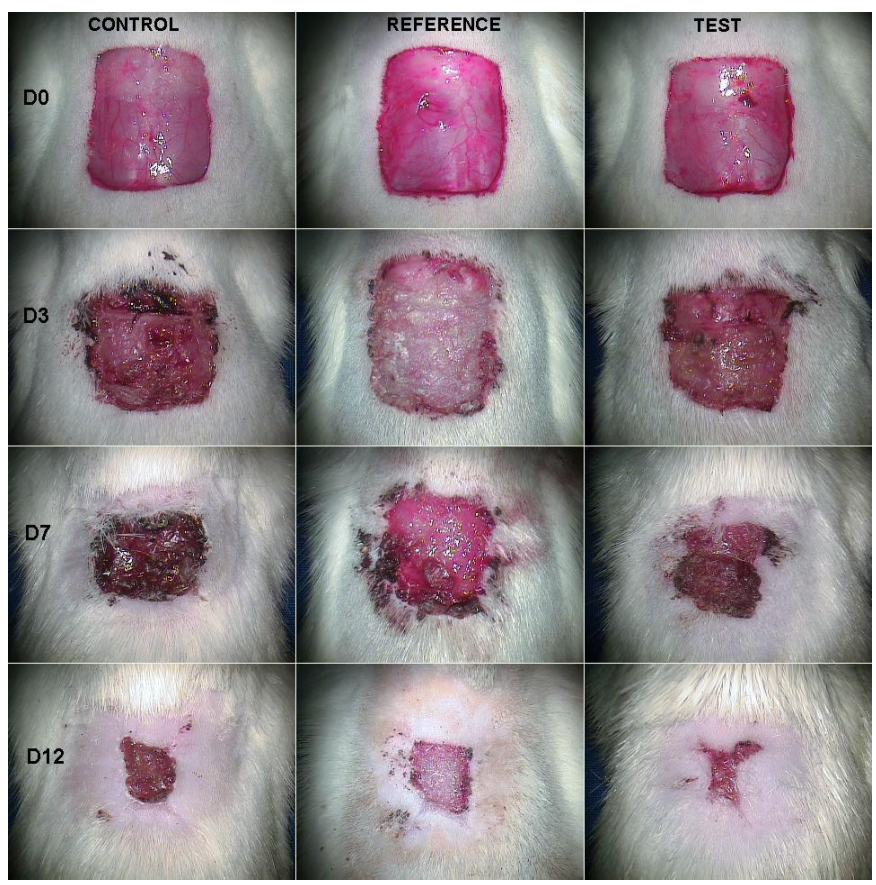

FIGURE 3 - Appearance of the ulcer on days 0, 3, 7 and 12 of treatment in the Control, Reference and Test groups. Magnification, 6X

Figure 4 illustrates the temporal development of the tissue repair process according to degree of repair $(D R)$. On the 3 rd day, a small decrease in the area of the ulcer was noted in relation to the initial values in Control $(10.2 \pm 6.97 \%)$ and Test $(8.45 \pm 6.20 \%)$ groups. On the contrary, in the Reference group, there was an increase in the ulcerated area, denoted by the negative $D R$ value (-11.31 $\pm 9.22 \%)$, which was significantly lower $(P<0.001)$ than that observed in the other two groups. On the $7^{\text {th }}$ day, the abrupt increase in $D R$ in the three groups (Control: $48.66 \pm 5.90 \%$; Reference: $30.18 \pm 16.21 \%$; Test: $53.06 \pm$ $7.81 \%$ ) showed a substantial reduction in the wound area. Nonetheless, the $D R$ value for the Reference group still remained significantly lower $(P<0.001)$ than that of the Control and Test 
groups. On the $12^{\text {th }}$ day, however, there were no statistically significant differences among the groups. In fact, a decrease in the slope of the $D R$ curve was seen in Control (77.95 $\pm 10.71 \%)$ and Test $(83.49 \pm 3.50 \%)$ groups, indicating that in relation to day 7 , the area of the ulcer regressed at a slower rate. On the other hand, in the Reference group, the tissue repair process proceded at the same intensity $(78.40 \pm 11.57 \%)$, as seen by the linear behavior of $D R$ in the period between the $3^{\text {rd }}$ and $12^{\text {th }}$ day.

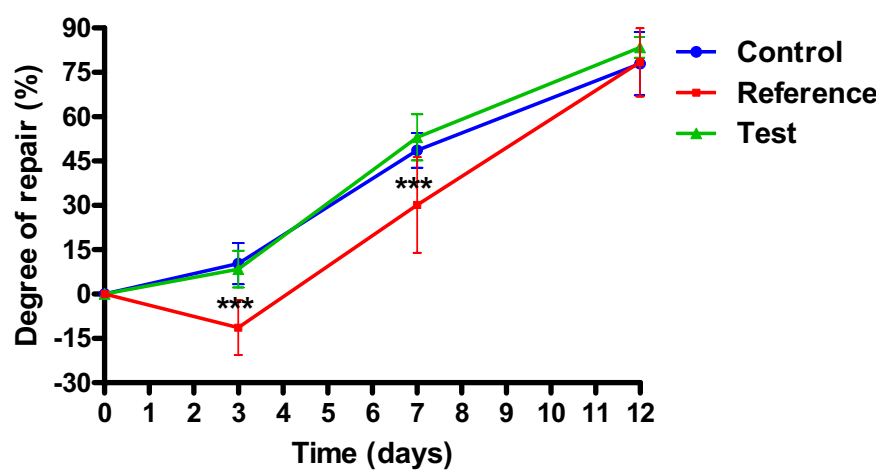

FIGURE 4 - Temporal development of the tissue repair process in the Control, Reference and Test groups, based on the degree of tissue repair $(D R)$. Data expressed as means and standard deviation of measurements for 15 animals of each group. Analysis of variance was used to compare the three groups, followed by Tukey's test to determine differences between all pairs of groups. No statistically significant differences were found. ${ }^{* * *} \mathrm{P}<0.001$. Reference lower than Control and Test (Tukey's test)

The kinetics of tissue repair can be better understood by the analysis of the variable mean rate of wound repair $(R R m)$ which represents the mean velocity of wound closing (Figure 5 ). In the period between days 0 and 3 , as a result of the expansion of the ulcerated area, $R R m$ for the Reference group was negative $\left(-14.77 \pm 12.59 \mathrm{~mm}^{2} /\right.$ day $)$ and significantly lower $(\mathrm{P}<$ $0.001)$ than that of Control (13.72 $\pm 9.57 \mathrm{~mm}^{2} /$ day) and Test $\left(11.33 \pm 8.29 \mathrm{~mm}^{2} /\right.$ day $)$ groups. In the interval between days 3 and 7, however, $R R m$ of the Reference group increased markedly $\left(40.61 \pm 17.52 \mathrm{~mm}^{2} /\right.$ day $)$, reaching values similar to that observed in the Control $\left(38.10 \pm 8.68 \mathrm{~mm}^{2} /\right.$ day $)$ and Test $(43.86$ $\pm 6.89 \mathrm{~mm}^{2} /$ day), such that no statistically significant differences were found. In this interval, in the three groups, $R R m$ reached their maximal values, characterizing the phase of greatest intensity of tissue repair. In the period between day 7 and 12 , on the other hand, there was a deceleration in the repair of the ulcer in the Control $\left(23.18 \pm 8.04 \mathrm{~mm}^{2} /\right.$ day $)$ and Test $(23.83$ $\pm 4.38 \mathrm{~mm}^{2} /$ day) groups, denoted by the diminution in the $R R m$ values. On the contrary, in the Reference group, $R R m$ remained practically unchanged $\left(37.37 \pm 6.15 \mathrm{~mm}^{2} /\right.$ day $)$, such that it was significantly greater than the of the other groups $(\mathrm{P}<0.001)$.

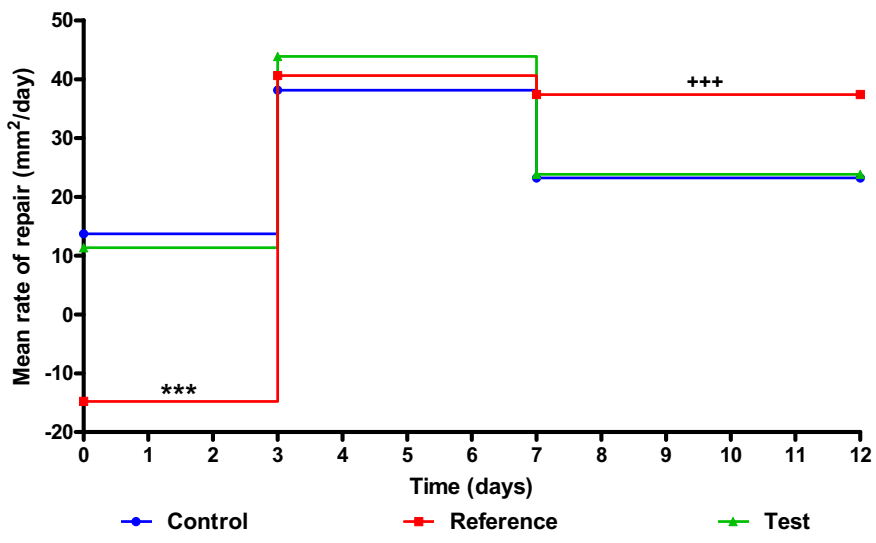

FIGURE 5 - Mean rate of wound repair $(R R m)$ for the intervals between days 0 and 3, 3 and 7, and 7 and 12. Data expressed as mean of measurements for 15 animals of each group. Analysis of variance was used to compare the three groups, followed by Tukey's test to determine differences between all pairs of groups. ${ }^{* * *} \mathrm{P}<0.001$ : Reference lower than Control and Test; +++ $\mathrm{P}<0.001$. Reference higher than Control and Test (Tukey's test)

Although $R R m$ by intervals revealed differences among the groups, $R R m$ overall, that is, that refering to the period between day 0 and 12 (Figure 6), was similar in the three groups: Control (25.79 $\pm 3.78 \mathrm{~mm}^{2} /$ day $)$, Reference $\left(25.42 \pm 4.76 \mathrm{~mm}^{2} /\right.$ day), Test $\left(27.38 \pm 1.95 \mathrm{~mm}^{2} /\right.$ day $)$. Therefore, there were no statistically significant differences found (Figure 6).

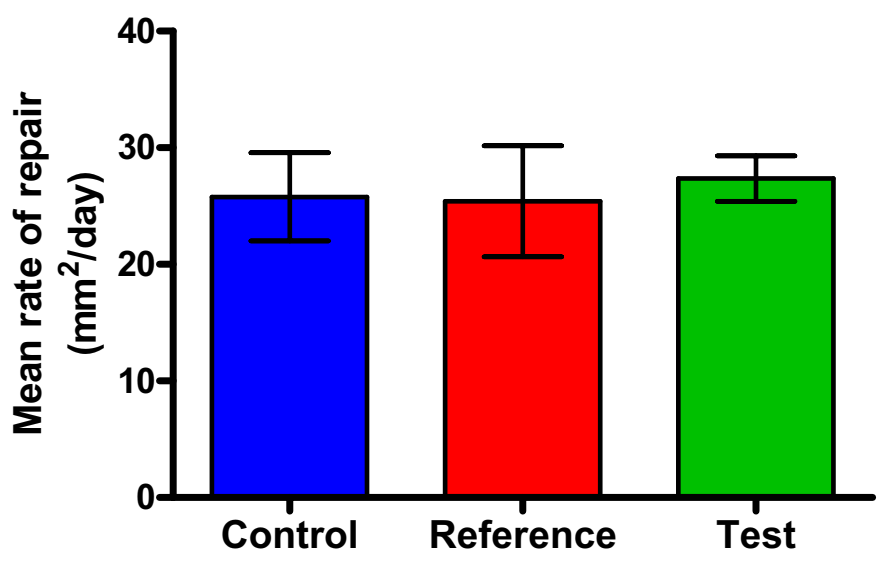

FIGURE 6 - Mean rate of wound repair $(R R m)$ for the interval between days 0 and 12. Data expressed as mean and standard deviation of the measurements from 15 animals of each group. Analysis of variance was used to compare the three groups, followed by Tukey's test to determine differences between all pairs of groups. No statistically significant differences were found

The efficacy of the treatments was determined relative to the control, based on the mean $D R$ for day 12 (Figure 7). In the Reference group, efficacy was $0.5775 \%$, while in the Test group it was $7.0977 \%$. Such percentages indicated that the treatments had effects similar to that of the control, albeit a slightly better effect with test treatment. 


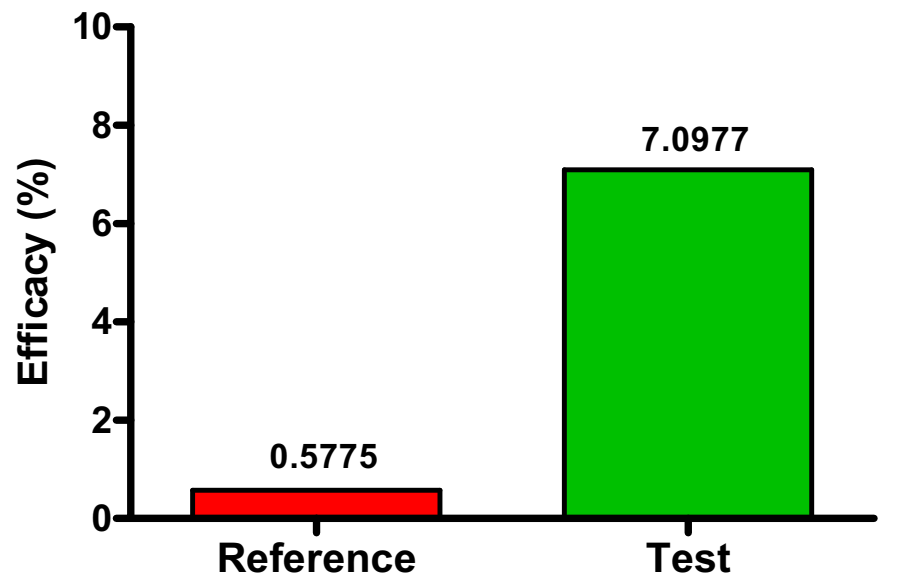

FIGURE 7 - Efficacy of the treatments calculated relative to the control on the $12^{\text {th }}$ day.

\section{Discussion}

In this study, the process of tissue repair of experimentally induced cutaneous wounds in rats was evaluated in vivo based on the kinetics of the regression of the ulcerated area over time. This was achieved by analyzing the variables that measure the degree of repair, which denotes the temporal contraction of the wound in relation to initial area, and mean rate of repair, that is, how many $\mathrm{mm}^{2}$ of the ulcer regressed per day.

To determine the above parameters, it was necessary to calculate the area of the wounds using a planimetric technique. Conventional planimetry consists of drawing the shape of the object of interest on graph paper and then counting the number of $\mathrm{mm}^{2}$ inside the demarcated region. However, we chose to use digital planimetry, since it is a more objective, rapid and accurate method, whose use has become commonplace $5,13,14,16$. Besides, digital images are a definitive documentation of the tissue repair, such that they can be utilized for later review or in additional studies.

A computer program (written by the second author) was developed specifically for the planimetry of anatomic structures. The proposal was to implement an easy-to-use software that would be an alternative to complex image analyzing systems of general use. The prior determination of the scale factor greatly facilitated the operation of the software, since it allowed actual measurements of the ulcerated region to be obtained, so that it was not necessary to place beside the wound an object such as a ruler or to measure on the animal one of the axes of the ulcer ${ }^{16}$.

The monitoring of the wound healing process in vivo requires successive measurements in the same experimental animal. In this way, the procedure of acquiring the digital images was standardized, in such a manner as to allow at different moments the capture of images of the wounds within the same frame. This strategy made it possible to detect, using the quantification software, the temporal variations in the area of the ulcer, even if minimal.
The image acquisition procedure combined with the quantification software constituted an accurate planimetric method which allowed the spatial and temporal monitoring of tissue repair in vivo. Such approach should be encouraged, for the purpose of dispensing with the sacrifice of animals, thereby requiring fewer experimental units to carry out assays.

Wound healing involves a complex and coordinated number of events which include inflammation, cell proliferation, contraction of the wound and tissue remodeling ${ }^{17}$. Thus, in this study, it was analyzed the effects of a combination of medium chain triglycerides (caprylic, capric, caproic and lauric acids), linoleic acid (essential fatty acid), soy lecithin and vitamins $\mathrm{A}$ and $\mathrm{E}$, applied topically, on this process in rats, considering the findings from earlier studies that demonstrated the efficacy of these agents in accelerating wound healing in human patients ${ }^{9}$.

In this study, subcutaneous cellular tissue was removed, making it necessary for the formation of new tissue for repair of the lesion. The combined use of neomycin and clostebol as in the Reference group was to evaluate the repair of the lesion, unlike in a study conducted earlier which evaluated antimicrobial activity ${ }^{18,19}$.

During the experiments, the protocol allowed us to photograph the animals on the day of the surgical procedure (zero), and on the $3^{\text {rd }}, 7^{\text {th }}$ and $12^{\text {th }}$ days of treatment. In this manner, besides the objective quantification, it was also possible to perform a subjective macroscopic clinical evaluation similar to that described in other studies carried out with the same test substance in $\operatorname{dogs}^{9}$ and with linoleic acid in sheep ${ }^{15}$.

Up to the $3^{\text {rd }}$ day, subjective observation indicated slow retraction of the wound in the Control group, with hyperemia and scab formation. In the Test group, hyperemia and discrete formation of scab on the edges of the lesion were observed. Hyperemia, edema and fibrin were seen in the Reference group. In another study in which the effects of polyunsaturated fatty acids on the healing of cutaneous wounds were evaluated, a macroscopic difference in lesion repair was demonstrated in the first $48 \mathrm{~h}$ after the surgical procedure ${ }^{8}$, which was not observed in our model.

The greater infiltration of polymorphonuclear cells and macrophages in the first three days can correspond to the phase of exudation and inflammation in the wounds treated with triglycerides as demonstrated in a study conducted in dogs. 9 In the same period in the present study, there were no signs of exudates by macroscopic observation.

From the $3^{\text {rd }}$ to the $7^{\text {th }}$ day, there was progressive repair of the wound area, which indicated development of granulation tissue in concordance with findings in the literature ${ }^{17}$. The macroscopic appearance showed the wound area with the presence of fibrin and scab in the Reference group, complete scab formation in the Control group, and discrete hyperemia in the Test group. It is likely that the occurrence of discrete signs compatible with inflammation such as edema and hyperemia after the third day could have been associated with the antioxidant action of vitamin E, minimizing reperfusion lesions as a consequence of the release of toxic free radicals, in agreement with the study conducted in dogs 9 . 
The action of soy lecithin provides hydration of the tissues, constituting a favorable factor in the repair of the lesion. Keeping the wound hydrated promotes autolytic debridement and contributes as a stimulus of epithelization, formation of granulation tissue and angiogenesis ${ }^{9}$. Thus, hydration promoted by soy lecithin, complemented by normal saline solution, made surgical debridement of the wounds unnecessary in this study. On the other hand, previous studies demonstrated that open and dried wounds undergo re-epitelization more slowly ${ }^{17}$.

From the $7^{\text {th }}$ to $12^{\text {th }}$ day, a greater rate of repair occurred in the Reference group. The test preparation showed evident granulation tissue and greater tissue contraction around the edges of the wound, which had become irregular. In the Control group, gaps in the scab were seen on the $7^{\text {th }}$ day, along with irregular edges due to contraction of the wound, besides the presence of granulation tissue. The Reference group remained with the largest wound area and with irregular edges, which was also found in a study using linoleic acid ${ }^{15}$. The treatments in the three groups contributed to the almost complete closing of the lesions, suggesting that growth factors were probably responsible for the hyperplasia of the epithelium as reported in the literature ${ }^{17}$. In this period, there was agreement with a study that considered cytokines as being important mediators of neoangiogenesis, fibroplasia and maturation, which are released by cells such as platelets, neutrophils, macrophages, lymphocytes, mast cells and fibroblasts, making it easy to understand the importance of chemotactic properties of the test preparation in the repair of the lesions ${ }^{9}$.

A study that examined wound healing in sheep showed that linoleic acid constituted a powerful pro-inflammatory mediator, being essential for the regulation of the biochemical events that precede fibroplasia in addition to stimulating growth factors and neovascularization ${ }^{15}$. It is possible that in this study the presence of linoleic acid in the test preparation contributed to a similar event.

A study carried out with polyunsaturated fatty acids showed a tendency for the wound area to diminish in the first ten days of treatment, and demonstrated overall that PUFAs may play an important role in wound healing ${ }^{8}$.

On the $12^{\text {th }}$ day, clinical observation showed a smaller wound area characterized by the proximity of the edges (contraction) with irregular outlines and better presence of granulation tissue, like that seen in the study with linoleic acid in sheep ${ }^{15}$.

Proliferation (fibroplasia and matrix formation) was demonstrated by scholars in the past as being extremely important in the formation granulation tissue. This depends on fibroblasts which produce elastin, fibronectin, glucosaminoglycans and proteases ${ }^{17}$. In this phase, the presence of vitamin $A$ in the test preparation was important, because authors evaluating the same preparation found that it stimulates fibroblasts, the deposition of collagen and formation of connective tissue ${ }^{9}$.

The repair of wounds by secondary union showed that contraction could have been responsible for the reduction in wound area in the three groups, in concordance with a study in which contraction was shown to be able reduce the surface of the cutaneous defect by $62 \%$.
In the model presented here, triglycerides favored a greater repair from a macroscopic clinical viewpoint, where it contributed to the wound area being less on the $12^{\text {th }}$ day of treatment. However, compared to Control group, the efficacy of the test preparation was only $7.0977 \%$, while the efficacy of the reference treatment was lower at only $0.5775 \%$.

\section{Conclusion}

The test preparation applied topically to the surgical wound produced in this model did not accelerate significantly the process of tissue healing by secondary union.

\section{References}

1. Carrel A. The treatment of wounds. JAMA. 1910;55:214850 .

2. Ortonne JP, Clévy JP. Physiology of cutaneous cicatrization. Rev Prat. 1994; 44(13):1733-7.

3. Araújo CFR, Souza Fo ZA, Greca FH, Guerreiro MHCPM, Leite AL, Mansur AE C, Kantor DC, Nassif AE. Effects of Agarol $^{\circledR}$ and Trigliceril ${ }^{\circledR}$ on cutaneous wound healing: experimental study in rats. Acta Cir Bras. 1998;13(4):232-7.

4. Banda MJ, Knighton DR, Hunt TK, Werb Z. Isolation of a nonmitogenic angiogenesis factor from wound fluid. Proc Nat Acad Sci. 1982;79:7773-7.

5. Mori, R.; Kondo, T.; Nishiie, T.; Ohshima, T.; Asano, M. Impairment of skin wound healing in $\beta$-1,4galactosyltransferase-deficient mice with reduced leukocyte recruitment. Am J Pathol. 2004;164(4):1303-14.

6. D’Agostini D. Obtenção de lipídíos estruturados por intereterificação de triacilglicerois de cadeia média e longa [Tese de Doutorado]. Universidade de São Paulo, Faculdade de Ciências Farmacêuticas; 2001.

7. Hatanaka E, Curi R. Fatty acids and wound healing: a review. RevRv Bras Farmacol. 2007;88(2):53-8.

8. Cardoso CRB, Souza MA, Ferro EAV, Favoreto S, Pena JDO. Influence of topical administration of $n-3$ and n- 6 essential and n-9 nonessential fatty acids on the healing of cutaneous wounds. Wound Rep Reg. 2004;12:235-43.

9. De Nardi AB, Rodaski S, Sousa RS, Baudi DLK, Castro JHT. Secondary cicatrization in dermoepidermal wounds treated with essential fatty acids, vitamins A and E, soy lecithin and polynylpyrrolidone-iodine in dogs. Arc Vet Sci. 2004;9(1):116

10. Ehrlich HP, Hunt TK. Effects of cortisone and vitamin A on wound healing. Ann Surg. 1968;167:324-8.

11. Greenway DLA \& Dyke KGH. Mechanism of the inhibitory action of linoleic acid on the growth of Staphylococcus aureus. J Gen Microbiol. 1979;115:233-45.

12. Moch D, Sheva T, Heihn H, Schimidt D, Buntroc P. The linoleic acid metabolite 2 Ds-hidroxi-10, 12 (E-Z): octadecadienoic acid is a strong, proinflammatory mediator in a experimental would healing model of the rat. Biom Biochem Acta. 1990;49:201-7. 
13. Teixeira VPA, Pereira SAL, Rodrigues DBR, Lino RSJ. Princípios básicos e aplicações da morfometria. Disponível em: http://www.uftm.edu.br/instpub/fmtm/patge/ morfometria01.htm. Acesso em: 17 jul.2007.

14. Mandarin-de-Lacerda, CA. Stereological tools in biomedical reserarch. An Acad Bras Cienc. 2003;75(4):469-86.

15. Marques SR, Peixoto CA, Messias JB, Albuqurque AR, Silva $\mathrm{Jr}$ VA. The effects of topical application of sunflower-seed oil on open wound healing in lambs. Acta Cir Bras. 2004;19(3):196209.

16.Martins NLP, Malafaia O, Ribas-Filho JM, Heibel M, Baldez RN, Vasconcelos PRL, Moreira H, Mazza M, Nassif PAN, Wallbach TZ. Healing process in cutaneous surgical wounds in rats under the influence of Orbignya phalerata aqueous extract. Acta Cir Bras. 2006;21(supl 3):66-75.

17. Mandelbaum SH, Di Santis EP, Mandelbaum MHSA. Cicatrization: current and auxiliary resources-Part 1. An Bras Dermatol. 2003;78(4):393-410.

18. Rodrigues KL, Cardoso CC, Caputo LR, Carvalho JCT, Fiorini JE, Schneedorf JM. Cicatrizing and antimicrobial properties of an ozonised oil from sunflower seeds. Inflammopharmacology. 2004;12(3):261-70.

19. Sakuma CH, Matera JM, Valente NS. Clinical study of skin flap application during oncologic surgery in dog. Bras J Vet Res Anim Sci. 2003;40 Suppl:32-7.

\section{Correspondence:}

Manoel Odorico de Moraes

Rua Cel. Nunes de Melo, 1127

60430-270 Fortaleza - Ceará Brazil

Phone: (55 85)3366-8201

odorico@ufc.br
Conflict of interest: none Financial source: none

Received: November 19, 2007

Review: January 23, 2008 Accepted: February 19, 2008

\section{How to cite this article}

Magalhães MSF, Fechine FV, Macedo RN, Monteiro DLS, Oliveira CC, Brito GAC, Moraes MEA, Moraes MO. Effect of a combination of medium chain triglycerides, linoleic acid, soy lecithin and vitamins A and E on wound healing in rats. Acta Cir Bras. [serial on the Internet] 2008 May-June;23(3). Available from URL: http://www.scielo.br/acb

\section{*Color figures available from www.scielo.br/acb}

